\title{
Urinary Incontinence in Elderly Women: Impact of Surgical Correction in Quality of Life and Occurrence of Bacteriuria
}

\author{
Nino José Wilson Moterani Júnior ${ }^{1 *}$, André Aranda Selverio ${ }^{2}$, Milena \\ Fernandes Castro ${ }^{2}$, Eduardo Federighi ${ }^{3}$ Baisi Chagas $^{3}$ and Zamir \\ Calamita $^{4}$ \\ ${ }^{1}$ Department of Gynecology and Obstetrics, Faculty of Medicine of Marilia, Brazil \\ ${ }^{2}$ Academic of medicine, Faculty of Medicine of Marilia, Brazil \\ ${ }^{3}$ Department of Biostatistics, Faculty of Medicine of Marilia, Brazil \\ ${ }^{4}$ Department of Immunology, Faculty of Medicine of Marilia, Brazil \\ *Corresponding Author: Nino José Wilson Moterani Júnior, Department of \\ Gynecology and Obstetrics, Faculty of Medicine of Marilia, Brazil.
}

Received: February 09, 2021

Published: February 27, 2021

(C) All rights are reserved by Nino José Wilson

Moterani Júnior., et al.

\begin{abstract}
An almost experimental study in which 19 elderly patients with stress urinary incontinence were submitted to surgical treatment by transobturator sling, with the main objective of evaluating the impact on the quality of life, through questionnaires validated and translated into Portuguese: International Consultation on Incontinence Questionnaire - Short Form and King's Health Questionnaire. The secondary objectives were to evaluate the occurrence of infectious and bacterial complications, by uroculture, before and after the surgical intervention. The sample consisted mainly of white women (78.9\%), above the normal body mass index, multiparous. The levels of asymptomatic bacteriuria before and after surgery were $15 \%$ and $5.3 \%$ respectively. There was improvement of all quality of life parameters in the questionnaires used. It was concluded that the surgical intervention had a positive impact on the quality of life of incontinent elderly women. Although there was a drop in the levels of asymptomatic bacteriuria in absolute numbers, there was no statistical significance.
\end{abstract}

Keywords: Aging; Bacteriuria; Quality of Life; Suburethral Slings; Urinary Incontinence

\section{Abbreviations}

cm: Centimeters; cmH20: Centimeters of Water; g: Grams; UI: Urinary Incontinence; BMI: Body Mass Index; ICIQ-SF: International Consultation on Incontinence Questionnaire - Short Form; KHQ: king`S Health Questionnaire; mL: Milliliter; mL/s: Milliliter Per Second; n: Sample Size; p: Value of Statistical Significance; POP-Q: Pelvic Organ Prolapse Quantification System; QL: Quality of Life; HRQL: Health-Related Quality of Life.

\section{Introduction}

The International Continence Society defines Urinary Incontinence (UI) as any objectively demonstrable involuntary loss of urine causing social or hygienic problems [1].
There is difficulty in determining the prevalence of urinary incontinence, because many women are reluctant to seek professional help, due to the embarrassment caused by the symptoms, or the perception that UI is a natural event of senility and that nothing can be done.

We know that UI is a condition which often happens along with the aging process; however, we should not understand it as a consequence of it, because there is great impact on the quality of life (QL) and, with the appropriate therapy, there are high rates of improvement.

The world life expectancy has increased progressively, and Brazil goes through the aging process of its population. Several risk factors for UI are associated to ageing (age, parity, hypoestrogen- 
ism, menopause). Therefore, the number of women affected by UI tends to grow [1-5].

The treatment must occur in a multidisciplinary way, aiming at the orientation of habits, weight loss, medication use, physiotherapy and surgeries. The surgical treatment of UI has evolved over the decades, reducing surgical time, bleeding, length of hospital stay, postoperative pain, return to normal activities and impact on quality of life $[6,7]$.

Among the surgical treatments, we highlight the approach using synthetic polypropylene slings via transobturator approach, in which there is the passage of a synthetic mesh strap through the obturator foramen, with the mesh positioned, free of tension, at the level of the middle urethra $[6,7]$.

Besides UI, another urological condition that affects women is bacteriuria, whose occurrence increases with age due to anatomical and structural changes in the aging process. Studies show association between UI and bacteriuria, with possible development of urinary infection, in elderly. However, the cause of this fact is not established. Urinary infections are among the main reasons for hospitalization, and also constitute an important cause of mortality related to infectious diseases in this population [8].

Therefore, UI and bacteriuria are correlated, and important public health problems. Urethral slings are the main surgical treatment for UI, and although synthetic mesh materials have evolved, infectious complications such as bacteriuria and operative wound infections are a constant concern. Studies with the general population do not establish a consensus on how to surgically approach these women to reduce complications. Data on antibiotic prophylaxis and time of bladder catheterization are conflicting. There are few data with groups consisting only of elderly women, which have several anatomical and systemic particularities.

Thus, we raise the following questions:

The treatment of stress urinary incontinence, through synthetic transobturator sling, causes improvement in the quality of life related to the health of elderly women with urinary incontinence?

The occurrence of infectious complications, in elderly women, are similar to the general population?
Thus, the desired objectives will be:

\section{Primary objective}

To evaluate the impact on the quality of life of women submitted to surgical treatment of stress urinary incontinence, by intrinsic sphincter defect, with synthetic polypropylene sling and "out-toin" transobturator approach.

\section{Secondary objectives}

To evaluate the presence of infectious complications before and after surgery, as well as sociodemographic, anthropometric, urodynamic, and other surgical complications.

\section{Methods}

This is an almost experimental, "before and after" type study, in which the same group of patients had their sociodemographic, anthropometric and quality of life profile evaluated, through structured and validated questionnaires, before and after surgical intervention for urinary incontinence. The levels of bacteriuria, urodynamic data and surgical complications were also evaluated.

The study started after approval in the Research Ethics Committee of the Faculdade de Medicina de Marília, CAEE number 83284017.7.0000.5413.

Nineteen women with 60 years of age or older, carriers of stress urinary incontinence, with a loss pressure of $60 \mathrm{cmH} 20$ or less to the urodynamic study, urinary flow equal to or greater than 18 $\mathrm{mL} / \mathrm{s}$ and post-mictional residue of less than $20 \%$ of the urine volume, and indication for surgical correction, were approached. The women, who agreed to participate in the study, responded to the Free and Informed Consent Term, according to Resolution 196/96 of the National Health Council.

The sample size (n) was determined to analyze the effect of the surgical intervention on the quality of life by means of the ICIQ-SF questionnaire using the $t$ student test for paired samples. A very large effect size (0.70) (TUNCER., et al 2016), a type I margin of error $(\alpha)$ of $5 \%$ and a study power of $80 \%$ indicating the need for a sample of 19 sample elements were considered for the sample calculation. The sample size was performed in $\mathrm{G}^{*}$ Power software, version 3.1.9.2 (Franz Faul, Universität Kiel, Germany) [9].

Patients with conditions that may directly impair the outcome of the surgery were excluded: blood clotting disorder, obstruction

Citation: Nino José Wilson Moterani Júnior., et al. "Urinary Incontinence in Elderly Women: Impact of Surgical Correction in Quality of Life and Occurrence of Bacteriuria". Acta Scientific Women's Health 3.3 (2021): 66-74. 
of the upper urinary tract, renal failure, impairment of the immune system, vaginal infection, having previously performed a sling procedure, presence of genital dystopia grade III or IV by the POP-Q classification.

From June 2018 to June 2019, 92 patients referred for urinary incontinence were seen at the urogynecology clinic, according to the following flow chart.

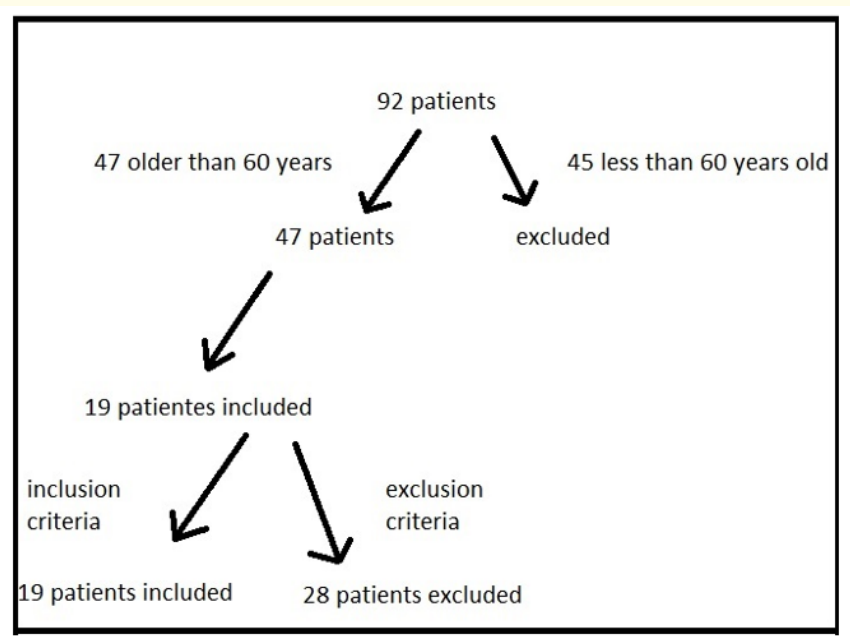

Figure 1

47 patients were 60 years old or older, 19 were included in the survey and 28 were excluded. Of these, ten (35.75\%) had urgency UI. Seven (25\%) for having loss pressure higher than $60 \mathrm{cmH} 20$ in the urodynamic exam, three $(10.7 \%)$ for having flow lower than $18 \mathrm{~mL} / \mathrm{s}$ in the same exam, three $(10.7 \%)$ for already having previous sling surgery, two (7.14\%) for refusing surgical treatment, two (7.14\%) for presenting uncompensated clinical comorbidities (one hypertension and diabetes, and another chronic obstructive pulmonary disease), and one (3.57\%) third degree genital dystopia in POP-Q (uterine prolapse).

To collect socio-demographic, anthropometric and medical data, we used a questionnaire prepared by us, based on clinical observations and theoretical assumptions available in the literature, contemplating: Anthropometrics - weight, height, body mass index (BMI); Sociodemographic - age, race, education, marital sta- tus; Medical - obstetrical background: numbers of vaginal births, cesarean sections, abortions, weight of the largest newborn, home or hospital births, sexual life, age of onset of menopause, intestinal constipation, chronic cough, physical activity.

Elderly people who perform medium-intensity aerobic physical activity for 150 minutes or more per week, or high-impact aerobic physical activity for 75 minutes or more per week were considered physically active. In case of reduced mobility, those who perform activities to improve balance and reduce falls at least three times a week were considered active [10].

Active sex life has been defined as the performance of strokes, preliminary caresses, masturbation, or sexual act (penetration of the peni into the vagina) [11].

Chronic cough was considered to last more than 8 weeks [12].

Constipation was defined as less than three bowel movements per week, associated with one of the following symptoms: hard stools, straining, feeling of incomplete evacuation, manual maneuvers to facilitate evacuation [13].

For the evaluation of QL we used two questionnaires translated and validated into Portuguese: ICIQ-SF and KHQ. Although the questionnaires were developed for self-application, due to the low level of education of our population, they were applied in the form of an interview, by two academics of the fourth year of medicine, duly trained, and without the participation of the doctor responsible for the surgery at the time of application.

After the application of the questionnaires, the patients collected the preoperative exams, including urine and uroculture summaries.

The surgery performed was the transobturatory synthetic sling, with an "out to in" approach, under hospital admission. The patients were not required to sanitize their vaginas before surgery. All procedures were done by the same surgeon, always following the same technique. For the surgery, the antibioticoprophylaxis was done with cephalothin, two grams, intravenously, 30 minutes before the beginning of the surgery, according to local protocol. The patients were placed in gynecological position under spinal anesthesia. Asepsis was performed with degerminating chlorhexedine. 
After the asepsis, a bladder catheterization of all patients was performed. At the end of the procedure, verified absence of hematuria, the patient was referred for anesthetic recovery. After 12 hours, the bladder catheter was removed, and if the patient was able to urinate spontaneously, and without complaints of hesitation, weak urinary jet or incomplete bladder emptying, she was discharged from hospital, which occurred with all patients. There was no prescription of antibiotics for the post-operative period.

Outpatient returns were scheduled seven, fourteen, thirty, sixty and ninety days after surgery. In these consultations complaints were registered suggestive of symptomatic bacteriuria (fever, chills, dysuria, polaciuria or supra-pubic pain), and the presence of postoperative complications was evaluated (hematomas, fistulas, infection of the operative wound, pain in the lower limbs, mesh extrusion, dyspareunia, hyspareunia, urinary retention). The operative wound infection was diagnosed when the patient presented persistent secretion from the incision, edema with or without pain, or dehiscence. The mesh extrusion was defined as the visualization of a mesh in the vagina after surgery. Urinary retention was recorded when the patient complained of hesitation, weak urinary jet or feeling of incomplete vesical emptying.

In the ninety-day postoperative consultation, the patients would again answer the quality of life questionnaires, and collect urine and uroculture summary samples. All postoperative consultations were performed by the same doctor.

Regarding the statistical analysis, the quantitative variables were described by mean and standard deviation. The qualitative variables were described by the relative (\%) and absolute (f) frequency distribution. The normality distribution was verified by the Shapiro-Wilk test. For comparison between groups, the t student test for paired samples or the non-parametric Wilcoxon test was performed. To analyze the differences in the proportion distribution of qualitative variables between the pre and postoperative moments, the McNemar test was used. Correlations between quantitative variables were analyzed by Pearson's test or Spearman's non-parametric test. For all analyses, the SPSS software version 19.0 for Windows was used, being adopted a $5 \%$ significance level.

\section{Results}

The socio-demographic data are expressed in the table below:

\begin{tabular}{|c|c|c|c|c|}
\hline \multicolumn{2}{|c|}{ Variables } & $\begin{array}{c}N \\
(19)\end{array}$ & $\%$ & $P$ value \\
\hline \multirow{4}{*}{ Race/Color } & White & 15 & 78,9 & \multirow{4}{*}{$<0,001$} \\
\hline & Brown & 1 & 5,3 & \\
\hline & Asian & 2 & 10,5 & \\
\hline & Black & 1 & 5,3 & \\
\hline \multirow{4}{*}{ Schooling } & None & 3 & 15,8 & \multirow{4}{*}{0,317} \\
\hline & $\begin{array}{l}\text { Elementary, } \\
\text { incomplete }\end{array}$ & 8 & 42,1 & \\
\hline & $\begin{array}{l}\text { Elementary, } \\
\text { complete }\end{array}$ & 3 & 15,8 & \\
\hline & $\begin{array}{l}\text { High school, } \\
\text { complete }\end{array}$ & 5 & 26,3 & \\
\hline \multirow[t]{3}{*}{ Marital Status } & Married & 12 & 63,2 & \multirow{3}{*}{0,021} \\
\hline & Widow & 4 & 21,1 & \\
\hline & Living together & 3 & 15,8 & \\
\hline Age & $\begin{array}{l}\text { Average } \\
64,9\end{array}$ & \multicolumn{2}{|c|}{$\begin{array}{l}\text { Median } \\
64\end{array}$} & $\begin{array}{l}\text { Standard } \\
\text { derivation } \\
15,93\end{array}$ \\
\hline
\end{tabular}

Table 1: Sociodemographic profile.

The anthropometric measurements of patients were noted. The average weight was $72 \pm 10.1$ kilos. The average height was $1.57 \pm$ 0.08 meters. The mean body mass index (BMI) was $29.2 \pm 3.8 \mathrm{~kg} /$ $\mathrm{m} 2$ (overweight). In normal BMI were two women (10.52\%), six with overweight (31.56\%), nine in grade 1 obesity $(47.25 \%)$, and two in grade 2 obesity (10.52\%).

Regarding the obstetric history, we observed that the average number of pregnancies was $4 \pm 2.24$. Eighteen patients (94.74\%) had previous gestations. Seventeen (89.48\%) had at least one vaginal delivery, and five (26.3\%) had a cesarean section. Five women $(26.3 \%)$ had at least one home birth. ( $p=0,039)$. The weight of the largest newborn was $2900 \mathrm{~g}$ to $4800 \mathrm{~g}$, with an average of $3239.5 \mathrm{~g}$. Four participants $(21.1 \%)$ had fetuses larger than $4000 \mathrm{~g}(\mathrm{p}=$ 0.012).

The practice of physical activity was reported by $52.6 \%$ of the interviewees. $(p=0,819)$. The active sexual life was $73.7 \%(p=$ 0.039).

The majority denied intestinal constipation (78.9\%) and chronic cough (84.2\%) (p 0.012 and 0.003, respectively). 
About the evaluation of QL, the impact of UI was measured through the KHQ and ICIQ-SF questionnaires. All domains of the KHQ presented important postoperative improvement, with statistical significance. Regarding the ICIQ-SF questionnaire, there was a high impact of UI on QL in the preoperative period, improving with statistical significance, according to the tables below:

\begin{tabular}{|l|c|c|c|c|c|}
\hline \multicolumn{2}{|c|}{ Pre operative evaluation } & \multicolumn{2}{c|}{ Post operative evaluation } \\
\hline Question & Average & $\begin{array}{c}\text { Standard } \\
\text { derivation }\end{array}$ & Medium & $\begin{array}{c}\text { Standard } \\
\text { derivation }\end{array}$ & p \\
\hline Frequency & 4,21 & 0,54 & 0,74 & 1,15 & $<0,001$ \\
\hline Amount & 4,53 & 1,61 & 1,05 & 1,68 & $<0,001$ \\
\hline Impact & 8,68 & 1,95 & 0,84 & 1,68 & $<0,001$ \\
\hline ICIQ-Score & 17,42 & 3,27 & 2,63 & 4,22 & $<0,001$ \\
\hline
\end{tabular}

Table 2: ICIQ-SF.

\begin{tabular}{|l|l|l|l|l|c|}
\hline \multicolumn{3}{|c|}{ Pre operative evaluation } & \multicolumn{3}{c|}{ Post operative evaluation } \\
\hline \multicolumn{1}{|c|}{ Domain } & Average & $\begin{array}{c}\text { Standard } \\
\text { derivation }\end{array}$ & Average & $\begin{array}{l}\text { Standard } \\
\text { derivaton }\end{array}$ & \multicolumn{1}{c|}{ p } \\
\hline $\begin{array}{l}\text { health } \\
\text { incontinence }\end{array}$ & 40,87 & 20,77 & 21,05 & 17,21 & 0,002 \\
\hline $\begin{array}{l}\text { 3-Role } \\
\text { limitations }\end{array}$ & 77,84 & 25,01 & 4,32 & 15,38 & $<0,001$ \\
\hline 4-Emotions & 63,42 & 33,33 & 9,31 & 24,59 & $<0,001$ \\
\hline $\begin{array}{l}\text { 5-Social } \\
\text { limitations }\end{array}$ & 49,95 & 30,81 & 1,74 & 7,57 & $<0,001$ \\
\hline $\begin{array}{l}\text { 6-Personal } \\
\text { relationships }\end{array}$ & 35,79 & 39,35 & 0,84 & 3,67 & 0,003 \\
\hline $\begin{array}{l}\text { 7-Sleep and } \\
\text { energy }\end{array}$ & 42,68 & 34,53 & 9,58 & 22,35 & 0,002 \\
\hline $\begin{array}{l}\text { 8-Severity } \\
\text { measures }\end{array}$ & 69,03 & 22,86 & 13,89 & 24,13 & $<0,001$ \\
\hline
\end{tabular}

Table 3: KHQ.

Regarding the occurrence of bacteriuria, no patient presented symptoms in the pre or postoperative period, therefore, there was no occurrence of symptomatic bacteriuria. However, three (15.8\%) presented asymptomatic bacteriuria in the preoperative period, being the pathogens isolated: Proteus mirabilis, Klebsiella pneu- monia and Escherichia coli, receiving antibiotic therapy before the surgery, according to antibiogram. In the postoperative period only one patient (5.3\%) presented altered uroculture, by Morganella morganii. $(\mathrm{p}=0,5)$. This patient also presented altered uroculture in the preoperative period.

The data from the urodynamic examination performed before surgery were described, according to the table below:

\begin{tabular}{|l|c|c|}
\hline \multicolumn{1}{|c|}{ Variable } & Average & $\begin{array}{c}\text { Standard } \\
\text { derivation }\end{array}$ \\
\hline $\begin{array}{l}\text { Initial urofluxometry, maximum } \\
\text { flow (mL/s) }\end{array}$ & 14,84 & 6,01 \\
\hline Initial urofluxometry, residue (mL) & 1,63 & 2,99 \\
\hline $\begin{array}{l}\text { Initial urofluxometry, urinary } \\
\text { volume (mL) }\end{array}$ & 210,1 & 204,71 \\
\hline Valsalva low leak point (cmH20) & 55,78 & 5,36 \\
\hline Maximum cistometric capacity (mL) & 425,26 & 115,05 \\
\hline $\begin{array}{l}\text { Voiding study, maximum flow } \\
\text { (mL/s) }\end{array}$ & 19,68 & 2,82 \\
\hline Voiding study, residue (mL) & 2,47 & 4,71 \\
\hline Voiding study, urinary volume (mL) & 423,94 & 115,02 \\
\hline
\end{tabular}

Table 4: Urodinamic examination.

We had no intraoperative complications (massive bleeding, bladder or urethra injury, vaginal laceration). The postoperative complications occurred in three patients (15.9\%): one (5.3\%) presented hematoma and pain in the right thigh in the first postoperative days, but there was resolution of the condition with rest and symptomatic medications. Two other patients (10.6\%) presented small mesh extrusions with two months postoperatively, both around $0.5 \mathrm{~cm}$ of mesh exposed. They were evaluated in the surgical center, under spinal anesthesia, being resected only the portion of the extruded mesh, and the mucosa was sutured again over the exposed area. After 3 months of this new intervention, both patients were asymptomatic and without exposed mesh. No patient presented infection of the operative wound.

\section{Discussion and Conclusion}

The age of the patients varied from 60 to 84 years, with an average of 64.9 years, which is slightly lower than the study by Evangelista and Calamita [14] to determine the prevalence of UI in elderly women of Marilia and region. This fact may be due to the 
research scenario, since our outpatient clinic is a tertiary service for treatment of UI. Elderly women may not seek specific care for this pathology due to shame, or have difficulty in seeking surgical treatment, because they demand greater postoperative assistance from the family, which is not always possible, especially in the socioeconomic profile of our users.

Most of our patients declared themselves white (78.9\%) and had a low level of schooling (57.9\% had incomplete or lower elementary schooling), data compatible with studies of the prevalence of UI in the Brazilian population $[6,14]$. The predominance of UI in the white race possibly occurs because they have genetically weaker musculature of the elevators of the anus $[15,16]$.

The average BMI was $29.2 \pm 3.8$, demonstrating overweight in the population studied. Several studies show a relationship between BMI and IU [17-19].

Constipation and chronic cough are reported risk factors for UTI. However, in our study only $21.1 \%$ reported problems of constipation, and $15.8 \%$ of chronic cough [18-21].

Regarding the obstetric history, we observed a population characterized by multiparous women, with mainly vaginal births, and part of these women had home births and, in some cases, macrosomal fetuses. These factors classically in the literature are described as increased risk for UI $[14,17,18]$. 94,74\% of the women had been pregnant. The average number of pregnancies was $4 \pm$ 2.24 . Vaginal birth occurred in $62 \%$ of the cases; $26.3 \%$ had at least one home birth. The average weight of newborns was $3239 \mathrm{~g}$ and $21 \%$ had fetuses over $4000 \mathrm{~g}$.

Among the sociodemographic data, those that presented statistical significance in the proportion distribution were: race, marital status, home births, previous surgery for incontinence, active sexual life, intestinal constipation, and chronic cough. Marital status should not directly influence the pathology, but only be a consequence of the type of population studied and the socio-cultural characteristics of our society.

The HRQL evaluation showed important improvements in both questionnaires applied, with statistical significance. The pre and post-operative moments of ICIQ-SF were compared, individually the questions three, four, five and the overall score. Each domain of KHQ was also compared, all with improvement. Tanuri., et al [6] evaluated a group of 10 women with improvement of all KHQ domains in a national study. Tuncer., et al [9] studied 49 patients, with a 6-month follow-up, and there was improvement of ICIQ-SF.

The three most affected domains of KHQ, before surgery, were "Incontinence impact", "Role limitations", and "Severity measures". In the postoperative "Role limitations" gave way to "General Health", this being the most affected domain. A study by Evangelista and Calamita [14], in a Geriatric Outpatient Clinic of the Faculty of Medicine of Marilia, verified the most affected domain "General health". Therefore, we can infer that the existence of other comorbidities related to the aging process, which do not influence the urinary incontinence, are maintained after the surgical intervention and affect the quality of life [19-23].

The analysis of data from urodynamic examinations revealed patients with good bladder emptying (mean maximum flow of $19.68 \mathrm{~mL} / \mathrm{s}$ and mean post-mictional residue of $2.47 \mathrm{~mL}$ to the myctional study), and with intrinsic sphincter defect (Valsalva leak point pressure of $55.78 \mathrm{cmH} 20$ ), therefore good candidates for surgical intervention. The adequate selection of patients, especially in elderly women, is one of the determining factors for the success of the surgery and low complication rates [21,22]. In our study, we opted for transobturator, instead of retropubic slings. Several studies demonstrate fewer complications with the transobturator approach, especially lower urinary retention, which may decrease the occurrence of bacteriuria. A study by Szymanski., et al. [24] evaluated QL and complications in groups with retropubic and transobturator slings, with a mean age of 59.6 years, finding less occurrence of urinary retention and infections in the transobturator approach.

Athanasiou., et al. [22] evaluated 72 patients, over 75 years old, submitted to transobturator slings when they were 60 years old or older, demonstrating good quality of life. Thus, considering the life expectancy of the Brazilian population, the transobturator approach, in elderly women, even with sphincter defects, seems to be very feasible.

We had no intra-operative complications. Our rate of postoperative complications, with a three-month follow-up, seems to match that of studies with non-elderly [19] and elderly population [1924]. A study by Lin., et al. [25] evaluated 50 patients, with a mean 
age of 62.2 years and also showed low rates of intra- and postoperative complications. There was an improvement in QL in an average follow-up of 18.5 months, although other questionnaires were used. Huang., et al. [26] obtained an improvement in QL and low rates of complications in a study with 78 women and a mean follow-up of 13.5 months, with a non-elderly population, and verified that the occurrence of complications did not hinder the improvement in QL. Most studies conclude that the rate of complications specific to the surgical procedure among non-elderly and elderly women is quite similar. A higher rate of complications can occur in elderly women related to comorbidities commonly presented by them, such as pulmonary dysfunctions and venous thrombosis; however, this was not the case in our study.

Specifically on the infectious complications, the data on the need of antibioticoprophylaxis and delay time of vesical catheterizetion are controversial in the literature. There are studies in the general population, but data are scarce for the elderly population, which we know has its anatomical and systemic particularities. Sanaee., et al. [27], in a recent meta-analysis, evaluated studies with middle urethral slings, with or without concomitant surgery for pelvic reconstruction, and some type of strategy, especially antibiotics, the outcome being the occurrence of infectious complications, especially bacteriuria. It is concluded that for middle urethral slings the antibiotic prophylaxis may be unnecessary [27]. Jackson., et al. [28] reported that the use of nitrofurantoin for the first three post-operative days of outpatient sling surgery may reduce the occurrence of post-operative bladder infection. Harmanli., et al. $[29,30]$ studied a sample of 147 subjects, who underwent either retropubic or transobturator slings, without prophylactic antibiotics, finding no operative wound infections, $1,4 \%$ of mesh exposure and $8 \%$ of bacteriuria, in a twelve month follow up. Propst., et al. [31], in a cohort of 7,117 patients, had the most common complication the urinary tract infection (one hundred eighty-seven occurrences), followed by wound infections (eight), pneumonia (three) and sepsis (three). Twenty-three patients needed sling revision or removal, which can be related to mesh extrusion. Increasing age was a risk factor for complications. Svenningsen., et al. [32] studied data of 28,687 patients who underwent mid-urethral slings, with or without prophylactic antibiotics (single dose first or second-generation cephalosporin with or without metronidazole), and reported that wound infection happened significantly more frequently in women not given prophylactic antibiotics. $(1.2 \%$, vs $0,6 \%$ when given antibiotics). Mangir., et al. [33], in his review, stated that vaginal asepsis and prophylactic antibiotics can be considered. However, there are no studies only with elderly women. As in our case, studies to evaluate infectious complications have not reached an adequate sample for this analysis, since the necessary number of participants is high and recruitment is very long. In any case, we consider our information important, since there are few data in the literature, especially for older women. In our study, we used antibiotic prophylaxis, with two grams of intravenous cephalothin, in the induction of anesthesia, according to local protocol. Our approach follows the recommendation of the American College of Obstetrics and Gynecology, which recognizes that this practice is based on expert opinion, not on solid data in the literature [27-30].

As strengths of our study we cite the elderly population approach, little evaluated in the national literature. The international literature has information about this population, but still little information about outcomes of infectious complications. Thus, we believe that our data can contribute to specific strategies for this audience. In addition, the standardization of behaviors, with surgeries and postoperative evaluations by the same surgeon, and the evaluation of QL questionnaires by the same academics, reduce the heterogeneity of information.

As a fragility we point out the size of our sample. It is the first time the authors research about this topic, and they plan to increase it in the future. Although the sample size is adequate for quality of life evaluation, more sample elements would be needed to study the infectious complications, however, due to their low occurrence, a long recruitment time would be required, which is why other studies also disclosed only preliminary data [27-30].

We concluded that transobturator slings, in older women, with the inclusion and exclusion criteria adopted by us, have a positive impact on quality of life, and low complication rates. There was a decrease in the levels of asymptomatic bacteriuria after the surgery, although without statistical significance. There were no cases of symptomatic bacteriuria or infection of the operative wound in our sample. We believe in the need for further studies on the subject to delimit specific surgical strategies for elderly women.

\section{Bibliography}

1. Honório MO and Santos SMA. "Incontinência urinária e envelhecimento: impacto no cotidiano e na qualidade de vida". Revista Brasileira de Enfermagem 62.1 (2009): 51-56. 
2. Leory LS and Lopes MHBM. "A incontinência urinária no puerpério e o impacto na qualidade de vida relacionada à saúde". Revista Latino Americana de Enfermagem 20.2 (2012): 346353.

3. Frade BA., et al. „Técnica modificada do sling pubovaginal no tratamento cirúrgico da incontinência urinária de esforço feminina". Revista do Colégio Brasileiro de Cirurgiões 42.6 (2015): 377-381.

4. Tamanini JTN., et al. "Validação do King's Health Questionnaire para o português em mulheres com incontinência urinária". Revista de Saúde Pública 37.2 (2003): 203-211.

5. Tamanini JTN., et al. "Validação para o português do International Consultation on Incontinence Questionnaire - Short Form (ICIQ-SF)". Revista de Saúde Pública.38.3 (2004): 438444.

6. Tanuri ALS., et al. "Sling retropúbico e transobturatório no tratamento da incontinência urinária de esforço". Revista da Associação Médica Brasileira 56.3 (2010): 348-354.

7. Stephen S., et al. "Choosing the right sling for your patient". Canadian Urological Association Journal 11.6 (2017): 132-134.

8. Cortes-Penfield NW., et al. "Urinary tract infection and asymptomatic bacteriuria in older adults". Infectious Disease Clinics of North America 31.4 (2017): 673-688.

9. Tuncer M., et al. "The effects of stress incontinence surgery on sexual function and life quality of women". Archivio Italiano di Urologia e Andrologia 88.2 (2016): 106-110.

10. Araújo CGS and Mesquita CT. "Physical activity, exercise and sport: a five-star path for a better cardiovascular health". International Journal of Cardiovascular Sciences 32.4 (2019): 313316.

11. Pacagnella RC., et al. "Validação de construto de uma versão em português do Female Sexual Function Index". Cadernos de Saúde Pública 25.11 (2009): 2333-2344.

12. Ryan NM., et al. "An update and systematic review on drug therapies for the treatment of refractory cough". Expert Opinion Pharmacotheraphy 19.7 (2018): 687-711.
13. Antunes MD., et al. "Constipação intestinal em idosos e a relação com atividade física, alimentação e cognição: uma revisão sistemática”. Revista de Medicina (São Paulo) 98.3 (2019): 202207.

14. Evangelista DR and Calamita Z. "Prevalência de incontinência urinária em idosas e impacto na qualidade de vida [dissertação]. Marília (SP)”. Faculdade de Medicina de Marília (2017).

15. Carvalho MP., et al. “O impacto da incontinência urinária e seus fatores associados em idosas". Revista Brasieleira de Geriatria e Gerontolologia. 17.4 (2014): 721-730.

16. Leroy LS., et al. "A incontinência urinária em mulheres e os aspectos raciais: uma revisão de literatura". Texto and Contexto Enfermagem 21.3 (2012): 692-701.

17. Komeilifar., et al. "The prevalence, subtypes and obstetric risk factors of urinary incontinence in reproductive age women referred to Community Health Care Centers of Dezful, Iran2015". International Journal of Community Based Nursing and Midwifery 5.3 (2017): 275-283.

18. Arya LA., et al. "Risk of new-onset urinary incontinence after forceps and vacuum delivery in primiparous women". American Journal of Obstetrics and Gynecololy 185.6 (2001): 13181323.

19. Linder BJ and Elliott DS. "Synthetic midurethral slings: roles, outcomes, and complications". Urologic Clinics of North America. 46.1 (2019): 17-30.

20. Lo TS., et al. "Outcomes and failure risks in mid-urethral sling insertion in elderly and old age with urodynamic stress incontinence". International Urogynecoly Journal 31 (2020): 717726.

21. Alas A., et al. "Are suburethral slings less successful in the elderly?". International Urogynecoly Journal 28 (2017): 553-559.

22. Athanasiou S., et al. "Women living with a midurethral sling in their 80s: long-term outcomes". International Urogynecoly Journal (2019).

23. Luz R., et al. "King`s Health Questionnaire to assess subjective outcomes after surgical treatment for urinary incontinence: 
can it be useful?" International Urogynecoly Journal 28 (2017): 139-145.

24. Szyamnski JK., et al. "Intraoperative and early postoperative complications in women with stress urinary incontinence treated with suburethral slings: a randomised trial". Wideochir Inne Tech Maloinwazyjne 15.1 (2020): 18-29.

25. Lin L., et al. "Comparison between tension-free vaginal tape and transobturator tape in treating stress urinary incontinence after vaginal mesh surgery". Taiwanese Journal of $\mathrm{Ob}$ stetrics and Gynecoly 57.4 (2018): 528-531.

26. Huang WC., et al. "Did surgical failure and complications affect incontinence-related quality of life in women after transobturator sling procedure?". Taiwanese Journal of Obstetrics and Gynecoly 57.2 (2018): 295-299.

27. Sanaee MS., et al. "Urinary tract infection prevention after midurethral slings in pelvic floor reconstructive surgery: a systematic review and meta-analysis". Acta Obstetrícia et Gynecolica Scandinavica 98.12 (2019): 1514-1522.

28. Jackson D., et al. "Antibiotic prophylaxis for urinary tract infection after midurethral sling: a randomized controlled trial". Female Pelvic Medicine and Reconstructive Surgery 19.3 (2013): 137-141.

29. Harmanli O., et al. "Is antibiotic prophylaxis necessary for midurethral sling procedures? A series of 174 cases without preoperative antibiotics". International Urogynecoly Journal 23.5 (2012): 621-623.

30. Harmanli O., et al. "Double-blinded randomized trial of preoperative antibiotics in midurethral sling procedures and review of the literature". International Urogynecoly Journal 22 (2011): 1249-1253.

31. Prospt K., et al. "Suburethral sling procedures in the United States: complications, readmission, and reoperation". International Urogynecology Journal 28 (2017): 1463-1467.

32. Svenningsen R., et al. "Is antibiotic prophylaxis necessary in mid-urethral sling surgery?" International Urogynecology Journal 32 (2021): 629-635.
33. Mangir N., et al. "Complications related to use of mesh implants in surgical treatment of stress urinary incontinence and pelvic organ prolapse: infection or inflamation?" World Journal of Urology 28 (2020): 73-80.

\section{Assets from publication with us}

- Prompt Acknowledgement after receiving the article

- Thorough Double blinded peer review

- Rapid Publication

- Issue of Publication Certificate

- High visibility of your Published work

Website: www.actascientific.com/

Submit Article: www.actascientific.com/submission.php Email us: editor@actascientific.com

Contact us: +919182824667 